\title{
The Role of Structural Defects in $\mathrm{MnO}_{\mathrm{x}}$ Promoted by Ag Doping in the Catalytic Combustion of VOCs and Ambient Decomposition of $\mathrm{O}_{3}$
}

Hua Deng1; Shunyu Kang ${ }^{1,2}$; Jinzhu Ma1,2,3*; Lian Wang³; Changbin Zhang ${ }^{2,3}$; Hong $\mathrm{He}^{1,2,3}$

${ }^{1}$ Center for Excellence in Regional Atmospheric Environment, Key Laboratory of Urban Pollutant Conversion, Institute of Urban Environment, Chinese Academy of Sciences, Xiamen, 361021, China

${ }^{2}$ University of Chinese Academy of Sciences, Beijing 100049, China

3 State Key Joint Laboratory of Environment Simulation and Pollution Control, Research Center for Eco-Environmental Sciences, Chinese Academy of Sciences, Beijing 100085, China

* Corresponding author. Tel: +86-010-62849337

E-mail address: jzma@rcees.ac.cn.

This Supporting Information contains:

Total number of pages: 18

Total number of Tables: 2

Total number of Figures: 12

This Supporting Information provides:

1. Text S1 Preparation Method.

2. Text S2 Catalytic Evaluation. 
3. Text S3 Material Characterization.

4. Figure S1. XRD patterns and Raman spectra for the series of Ag-MnOx catalysts.

5. Figure S2. FESEM images of Ag-MnOx catalysts.

6. Figure S3. HAADF-STEM and elemental mapping of different Ag-MnOx catalysts.

7. Figure S4. TEM/nanorod length distribution of Ag-MnOx catalysts.

8. Figure S5. The XPS binding energies of $\mathrm{Ag} 3 \mathrm{~d}$ for all $\mathrm{Ag}-\mathrm{MnOx}$ samples.

9. Figure S6. Comparison of $\mathrm{C}_{6} \mathrm{H}_{6}$ conversion (at $\mathrm{SV}=90000 \mathrm{mLh}^{-1} \mathrm{~g}^{-1}$ ) between Ag-MnOx-H and $1 \mathrm{wt} \% \mathrm{Pd} / \mathrm{Al}_{2} \mathrm{O}_{3}$.

10. Table S1 Summary of benzene oxidation or ozone decomposition catalysts known to exhibit good performance.

11. Figure $\mathrm{S} 7 . \mathrm{C}_{6} \mathrm{H}_{6}$ conversion with ozone assistance over $\mathrm{Ag}-\mathrm{MnO}_{\mathrm{x}}-\mathrm{H}$ catalyst as a function of temperature.

12. Figure S8. Normalized Mn-K XANES for series of Ag-MnOx catalysts.

13. Figure S9. Mn 3s XPS spectra of different Ag-MnOx catalysts

14. Figure $\mathrm{S} 10 . \mathrm{Mn} 3 \mathrm{~s}$ XPS spectra of pristine $\mathrm{Mn}_{2} \mathrm{O}_{3}$ catalyst.

15. Table S2 Peak-fitting parameters of O 1s spectra for Ag-MnOx catalysts.

16. Figure $\mathrm{S} 11$. The correlation between $\mathrm{O}_{3}$ decomposition rate and Henry's law constant of water vapor adsorption

17. Figure S12. EXAFS spectra of Mn-edge in series of Ag-MnOx catalysts in $\mathrm{k}$ space.

18. References. 


\section{Text S1}

Hydrothermal method. An appropriate amount of silver nitrate mixed with $18.34 \mathrm{~g}$ of manganous acetate was dissolved in deionized water under stirring. 12.5 $\mathrm{mL}$ glacial acetic acid was then added in order to form an acidic environment. Next, a solution of $10.84 \mathrm{~g}$ potassium permanganate in deionized water was added slowly to the above mixture under stirring (the optimum $\mathrm{Ag}$ to $\mathrm{Mn}$ mole ratio was controlled at 1 to 40). Finally, the mixed solution was maintained at $100{ }^{\circ} \mathrm{C}$ for $24 \mathrm{~h}$ in a $500 \mathrm{~mL}$ Teflon-lined autoclave and then cooled to room temperature. The resulting black slurry was centrifuged, washed with deionized water and dried at $100{ }^{\circ} \mathrm{C}$ overnight. Then the sample was calcined in a furnace at $500{ }^{\circ} \mathrm{C}$ for $3 \mathrm{~h}$. The final samples were denoted as $\mathrm{Ag}-\mathrm{MnO}_{\mathrm{x}}-\mathrm{H}$.

Impregnation method. The $\mathrm{Ag}-\mathrm{MnO}_{\mathrm{x}}-\mathrm{I}$ sample was prepared by the impregnation method using previously prepared $\mathrm{MnO}_{\mathrm{x}}$ powder $(5 \mathrm{~g}$, Mn content was obtained by ICP-OES firstly) and an aqueous solution of silver nitrate (the Ag to $\mathrm{Mn}$ mole ratio was controlled at 1 to 40). After impregnation, the excess water was removed using a rotary evaporator at $60{ }^{\circ} \mathrm{C}$. The sample was first dried at $100{ }^{\circ} \mathrm{C}$ overnight followed by calcination at $500{ }^{\circ} \mathrm{C}$ in air for $3 \mathrm{~h}$.

Co-precipitation method. An appropriate amount of silver nitrate mixed with $24 \mathrm{~g}$ of manganous acetate was dissolved in $370 \mathrm{ml}$ deionized water at the required mass ratio (the precursor $\mathrm{Ag}$ to $\mathrm{Mn}$ mole ratio was controlled at 1 to 40). Excess urea (64 g) was then added to the mixed solution under stirring. The solution was heated to $90{ }^{\circ} \mathrm{C}$ and maintained for $24 \mathrm{~h}$ under vigorous stirring. After filtration and washing with deionized water, the resulting precipitate was dried at $100{ }^{\circ} \mathrm{C}$ overnight and subsequently calcined in a furnace at $500{ }^{\circ} \mathrm{C}$ for $3 \mathrm{~h}$. The sample prepared by this homogeneous coprecipitation method was denoted as $\mathrm{Ag}-\mathrm{MnO}_{\mathrm{x}}-\mathrm{C}$. 


\section{Text S2}

Catalytic Evaluation. The catalytic oxidation of benzene was used as a model reaction [31] to evaluate the catalysts. The catalytic combustion tests for benzene were conducted in a fixed-bed continuous flow quartz reactor $(8 \mathrm{~mm}$ i.d.) at temperatures from $150-400{ }^{\circ} \mathrm{C}$. About $0.2 \mathrm{~g}$ of catalyst was used for each experiment. The gas flow passing through the reactor was $\mathrm{C}_{6} \mathrm{H}_{6}(1500 \mathrm{ppm})$, water vapor $(5 \%$, when used), and $\mathrm{O}_{2}(20 \%)$ in $\mathrm{N}_{2}$ balance at $300 \mathrm{~mL} / \mathrm{min}$. The GHSV value was 45000 $\mathrm{h}^{-1}\left(\mathrm{SV}=90000 \mathrm{mLh}^{-1} \mathrm{~g}^{-1}\right)$. The benzene concentration was analyzed online by a gas chromatograph (GC; Agilent 7890B, HP-5 capillary column) with a flame ionization detector. $\mathrm{CO}_{2}$ and $\mathrm{O}_{2}$ concentrations were analyzed by the same $\mathrm{GC}$ equipped with a thermal conductivity detector (Porapak Q and HayeSep Q column). In order to determine the carbon balance precisely, $\mathrm{CO}_{2}$ and $\mathrm{CO}$ concentrations were analyzed by the same GC equipped with a nickel catalyst tube and a flame ionization detector. The detection accuracy is about $1 \mathrm{ppm} . \mathrm{C}_{6} \mathrm{H}_{6}$ conversion was calculated using the following equation:

$$
\mathrm{C}_{6} H_{6} \text { Conversion }(\%)=\left(1-\frac{\left[C_{6} H_{6}\right]_{\text {out }}}{\left[C_{6} H_{6}\right]_{\text {in }}}\right) \times 100 \%
$$

The $\mathrm{CO}_{2}$ yield was defined as follows:

$$
\mathrm{CO}_{2} \quad \text { Yield }(\%)=\frac{\left[\mathrm{CO}_{2}\right]_{\text {out }}}{\left[\mathrm{C}_{6} \mathrm{H}_{6}\right]_{\text {in }} \times 6} \times 100 \%
$$

The ozone decomposition tests were conducted in a fixed-bed continuous flow quartz reactor $\left(4 \mathrm{~mm}\right.$ i.d.) at temperature $25^{\circ} \mathrm{C}$. About $0.1 \mathrm{~g}$ of catalyst was used for each experiment. The gas flow passing through the reactor was 1400 $\mathrm{mL} / \mathrm{min}$, with $280 \mathrm{~mL} / \mathrm{min} \mathrm{O}_{2}$ and $\mathrm{N}_{2}$ balance, and water vapor $(\mathrm{RH}=60 \%$ when used). The ozone inlet concentration was $40 \mathrm{ppm}$. The GHSV value was $420000 \mathrm{~h}^{-1}\left(\mathrm{SV}=840000 \mathrm{mLh}^{-1} \mathrm{~g}^{-1}\right)$. The other experimental details can be found in our previous study [28]. Ozone decomposition conversion was calculated using the following equation:

$$
O_{3} \text { Conversion }(\%)=\left(1-\frac{\left[O_{3}\right]_{\text {out }}}{\left[O_{3}\right]_{\text {in }}}\right) \times 100 \%
$$




\section{Text S3}

Material Characterization. The X-ray powder diffraction patterns of the catalysts were recorded by an X'Pert Pro XRD diffractometer (PANalytical B.V., Netherlands) with $\mathrm{CuK} \alpha$ radiation $(\lambda=1.5406 \AA)$ at $40 \mathrm{kV}$ and $40 \mathrm{~mA}$. Raman spectra were recorded on a laser Raman spectrometer (LabRAM Aramis, HORIBA Jobin Yvon, France) and excitation was provided by an He-Ne laser $(633 \mathrm{~nm})$. The morphology of catalysts was imaged using a Hitachi S-4800 scanning electronic microscope (Hitachi, Japan). Nitrogen adsorption-desorption isotherms were measured using a Quantachrome Autosorb IQ-X system at 77K. HAADF-STEM, elemental mapping and high-resolution transmission electron microscopy (HRTEM) were performed on a JEOL JEM-ARM2100F TEM with a Cs-corrected probe operated at $200 \mathrm{kV}$. X-ray photoelectron spectroscopy (XPS) measurements were carried out with an ESCALAB250 spectrometer using a monochromated A1 Ka X-ray source (1486.6 eV). Elemental analysis was conducted using an inductively coupled plasma emission spectrometer (ICP-OES, Optima 7000DV). The $\mathrm{H}_{2}$-TPR and CO-TPD were performed on a Micromeritics instrument (AutoChem 2920).
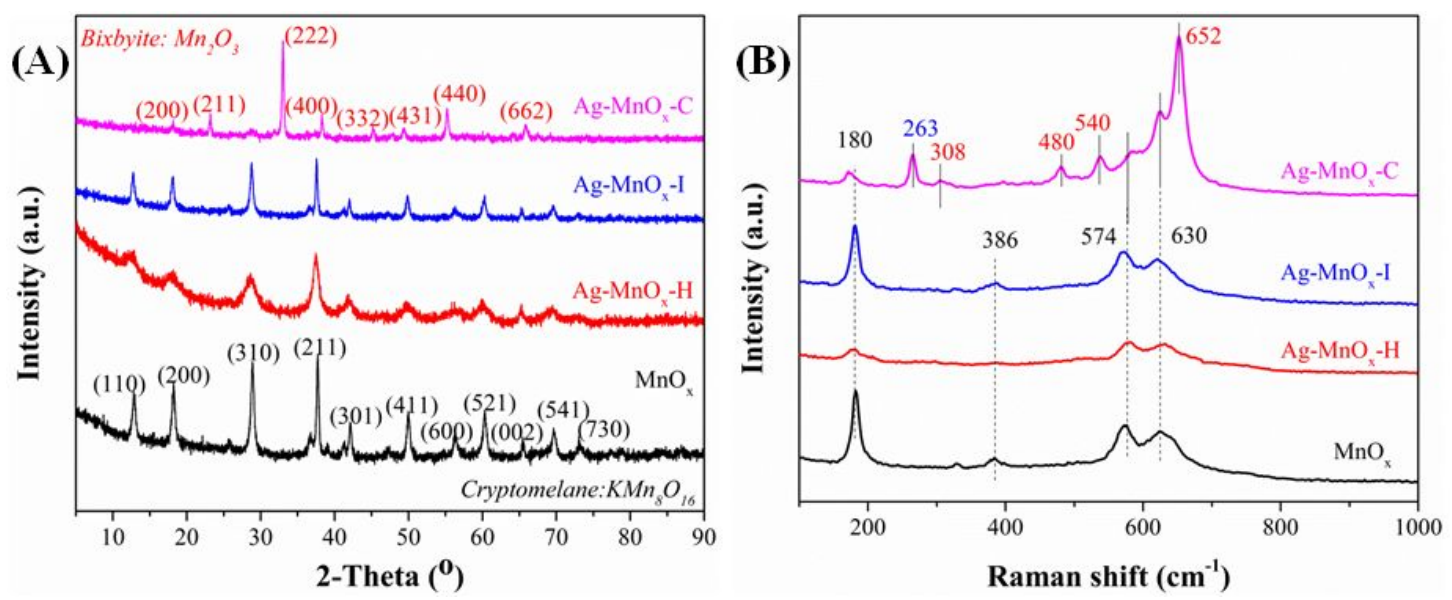

Figure S1. (A) XRD patterns, (B) Raman spectra for the series of $\mathrm{Ag}-\mathrm{MnO}_{\mathrm{x}}$ catalysts. $\mathrm{MnO}_{\mathrm{x}}, \mathrm{Ag}-\mathrm{MnO}_{\mathrm{x}}-\mathrm{H}$ and $\mathrm{Ag}-\mathrm{MnO}_{\mathrm{x}}-\mathrm{I}$ exhibited similar diffraction patterns. The $2 \theta$ values obtained $(12.7,18.0,28.7,37.4,41.8,50.0,55.3,60.0,65.3,69.8$, and 72.3 degrees) match well with the reflections ((110), (200), (310), (211), (301), (411), 
(600), (521), (002), (541) and (730) respectively) of synthetic cryptomelane-type $\mathrm{MnO}_{2}\left(\mathrm{ICDD}\right.$ No. $\left.00-29-1020, \mathrm{Mn}_{\mathrm{x}} \mathrm{O}_{\mathrm{y}}, \mathrm{y} / \mathrm{x}=2 / 1\right)$ [1-5]. It is worthy of note that the characteristic diffraction peaks related to $\mathrm{Ag}-\mathrm{MnO}_{\mathrm{x}}-\mathrm{H}$ were broadened and decreased in intensity. This result indicates that hydrothermal incorporation of silver in $\mathrm{MnO}_{\mathrm{x}}$ causes more significant crystalline structure variation than that introduced by impregnation, which may benefit the catalytic performance via decreasing the crystallinity. By contrast, co-precipitation of silver with a Mn precursor gave rise to the product $\mathrm{Ag}-\mathrm{MnO}_{\mathrm{x}}-\mathrm{C}$, which exhibited a quite different diffraction pattern. The reflections and $2 \theta$ values obtained are characteristic of bixbyite. The set of (h k 1) values (200), (211), (222), (400), (332), (431), (440), (662) for reflections at $2 \theta=18.2$, $23.2,33,38.3,45.2,49.4,55.3$ and 65.8 degrees, respectively, match the patterns of $\alpha-\mathrm{Mn}_{2} \mathrm{O}_{3}$ (ICDD No. 00-041-1442, $\mathrm{Mn}_{\mathrm{x}} \mathrm{O}_{\mathrm{y}}, \mathrm{y} / \mathrm{x}=3 / 2$ ) [6-7]. No additional peaks assignable to compounds of silver species appeared in these materials, revealing that the silver species were all highly dispersed.

The $\mathrm{MnO}_{\mathrm{x}}$ sample exhibited four distinct Raman peaks of $\mathrm{K}-\mathrm{OMS}-2 / \alpha-\mathrm{MnO}_{2}$ at bands of $180,386,574$ and $630 \mathrm{~cm}^{-1}$ [8-9]. Hydrothermal incorporation of silver into $\mathrm{MnOx}$ resulted in Raman spectral characteristics similar to those of unmodified $\alpha-\mathrm{MnO}_{2}$, but the spectrum of $\mathrm{Ag}-\mathrm{MnO}_{\mathrm{x}}-\mathrm{H}$ became weaker and broader, which reveals that the particle size of the samples decreased due to a size-dependent phenomenon commonly observed with nanoparticles [10]. The $\mathrm{Ag}-\mathrm{MnO}_{\mathrm{x}}-\mathrm{I}$ sample exhibited the same Raman spectrum as unmodified $\alpha-\mathrm{MnO}_{2}$. This is consistent with the XRD results, wherein silver impregnation maintained the structure of $\alpha-\mathrm{MnO}_{2}$ in a more intact state than that in $\mathrm{Ag}-\mathrm{MnO}_{\mathrm{x}}-\mathrm{H}$. As for Ag-MnOx-C, Raman peaks at 180, 574 and $630 \mathrm{~cm}^{-1}$ related to $\alpha-\mathrm{MnO}_{2}$ could also be found, accompanied by several new peaks. The main bands at $652 \mathrm{~cm}^{-1}$ correspond to the symmetric stretching of $\mathrm{MnO}_{\mathrm{x}}$ groups in $\mathrm{Mn}_{2} \mathrm{O}_{3}$ [6-7]. The asymmetric stretching of bridging oxygen species (Mn-O-Mn) $[6,7,11]$ related to $\mathrm{Mn}_{2} \mathrm{O}_{3}$ bands at 480 and $540 \mathrm{~cm}^{-1}$ could also be observed. The out-of-plane bending modes of $\mathrm{Mn}_{2} \mathrm{O}_{3}[6,7]$ were detected at $308 \mathrm{~cm}^{-1}$. However, the appearance of a Raman band at $263 \mathrm{~cm}^{-1}$ could not be ascribed to any $\mathrm{MnO}_{\mathrm{x}}$ phases. In fact, it is close to the symmetric bending mode $(\delta \mathrm{s}(\mathrm{O}-\mathrm{Ag}-\mathrm{O}))$ of 
$\mathrm{AgO}[12]$. Therefore, we can postulate that silver species were more aggregated in $\mathrm{Ag}-\mathrm{MnO}_{\mathrm{x}}-\mathrm{C}$ than in $\mathrm{Ag}-\mathrm{MnO}_{\mathrm{x}}-\mathrm{H}$ and $\mathrm{Ag}-\mathrm{MnO}_{\mathrm{x}}-\mathrm{I}$ in spite of the fact that all silver species were well dispersed.
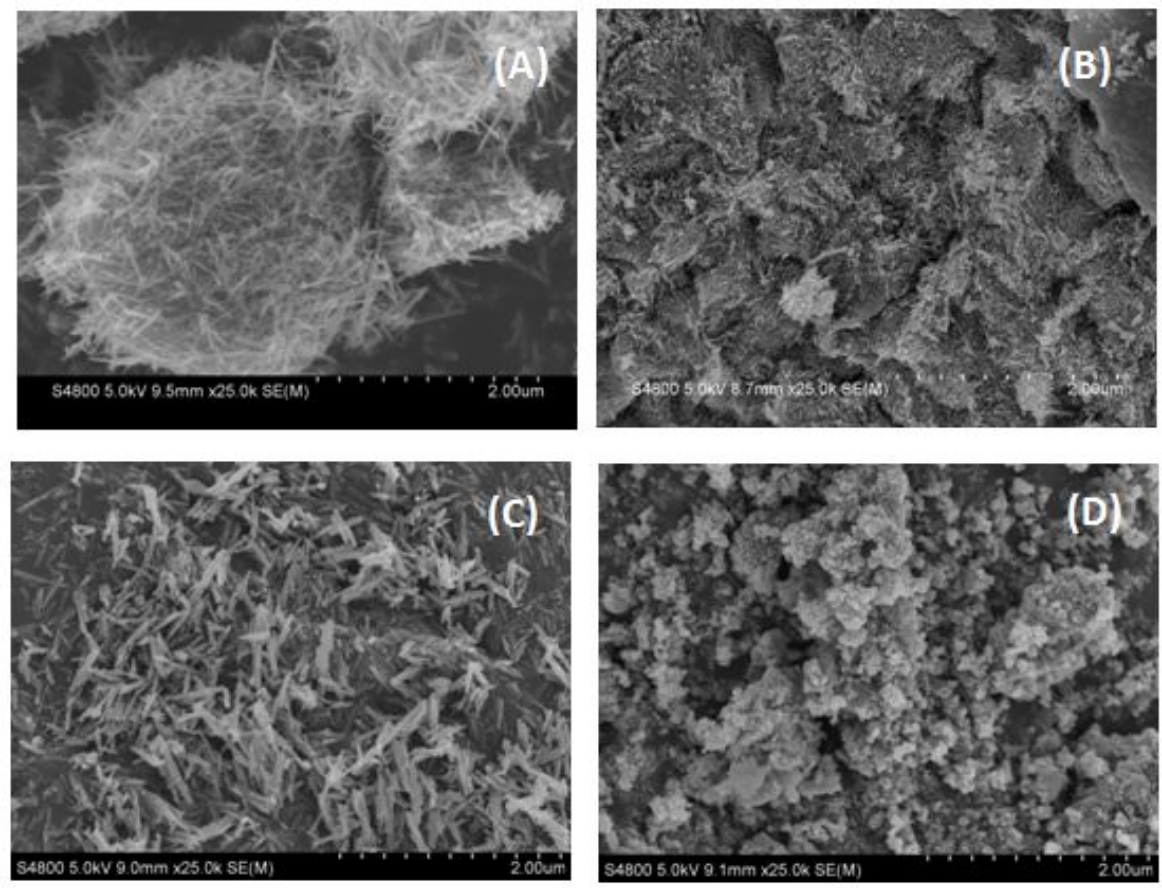

Figure S2. FESEM images of Ag- $\mathrm{MnO}_{\mathrm{x}}$ catalysts (A) $\mathrm{MnO}_{\mathrm{x}}$, (B) $\mathrm{Ag}-\mathrm{MnO}_{\mathrm{x}}-\mathrm{H}$, (C)

$$
\text { Ag- } \mathrm{MnO}_{\mathrm{x}}-\mathrm{I} \text {, (D) } \mathrm{Ag}-\mathrm{MnO}_{\mathrm{x}}-\mathrm{C} \text {. }
$$

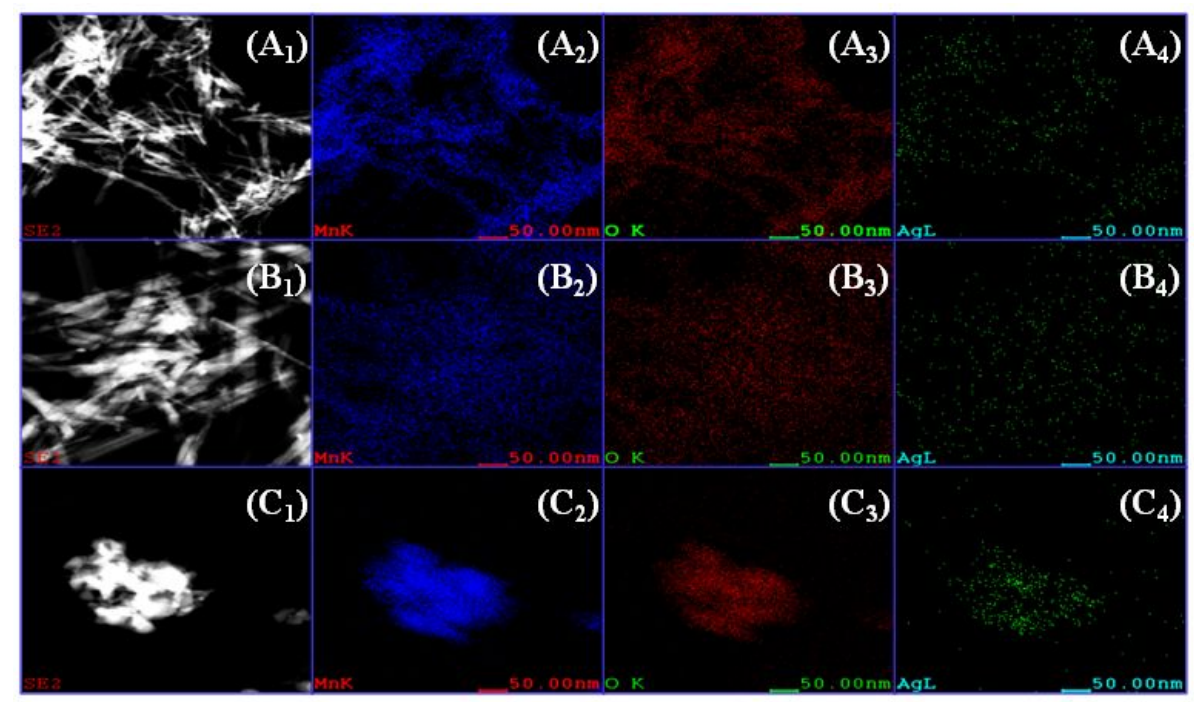

Figure S3. HAADF-STEM and elemental mapping of different $\mathrm{Ag}-\mathrm{MnO}_{\mathrm{x}}$ catalysts,

$$
\left(\mathrm{A}_{1}-\mathrm{A}_{4}\right): \quad \mathrm{Ag}-\mathrm{MnO}_{\mathrm{x}}-\mathrm{H}, \quad\left(\mathrm{B}_{1}-\mathrm{B}_{4}\right): \quad \mathrm{Ag}-\mathrm{MnO}_{\mathrm{x}}-\mathrm{I}, \quad\left(\mathrm{C}_{1}-\mathrm{C}_{4}\right): \quad \mathrm{Ag}-\mathrm{MnO}_{\mathrm{x}}-\mathrm{C}, \quad\left(\mathrm{X}_{1}\right)
$$


HAADF-STEM, $\left(\mathrm{X}_{2}\right)$ Mn-element mapping, $\left(\mathrm{X}_{3}\right)$ O-element mapping, $\left(\mathrm{X}_{4}\right)$ Ag-element mapping.
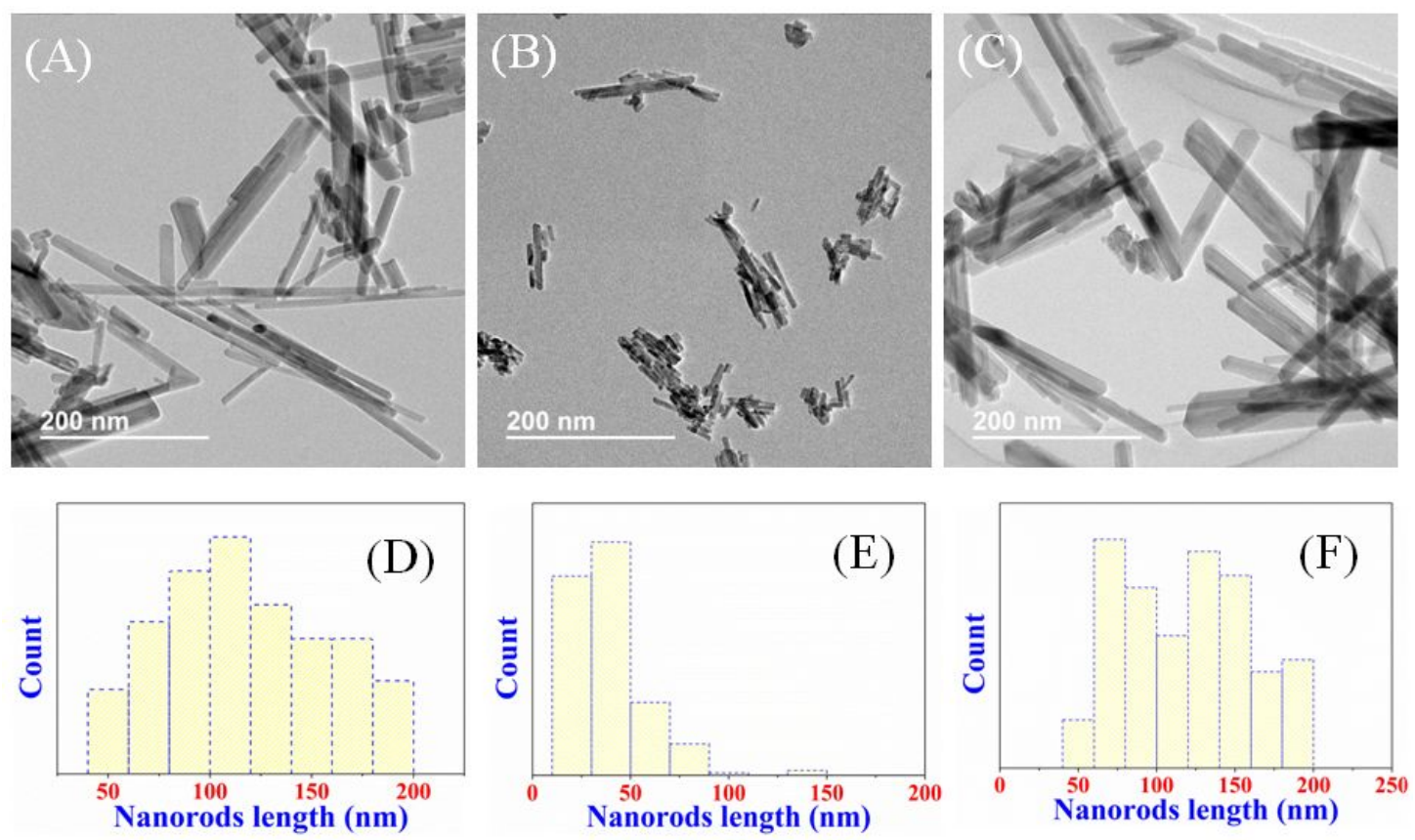

Figure S4. TEM/nanorod length distribution of $\mathrm{Ag}-\mathrm{MnO}_{\mathrm{x}}$ catalysts: $\mathrm{MnO}_{\mathrm{x}}(\mathrm{A}$ and $\mathrm{D})$, $\mathrm{Ag}-\mathrm{MnO}_{\mathrm{x}}-\mathrm{H}(\mathrm{B}$ and $\mathrm{E})$ and $\mathrm{Ag}-\mathrm{MnO}_{\mathrm{x}}-\mathrm{I}(\mathrm{C}$ and $\mathrm{F})$.

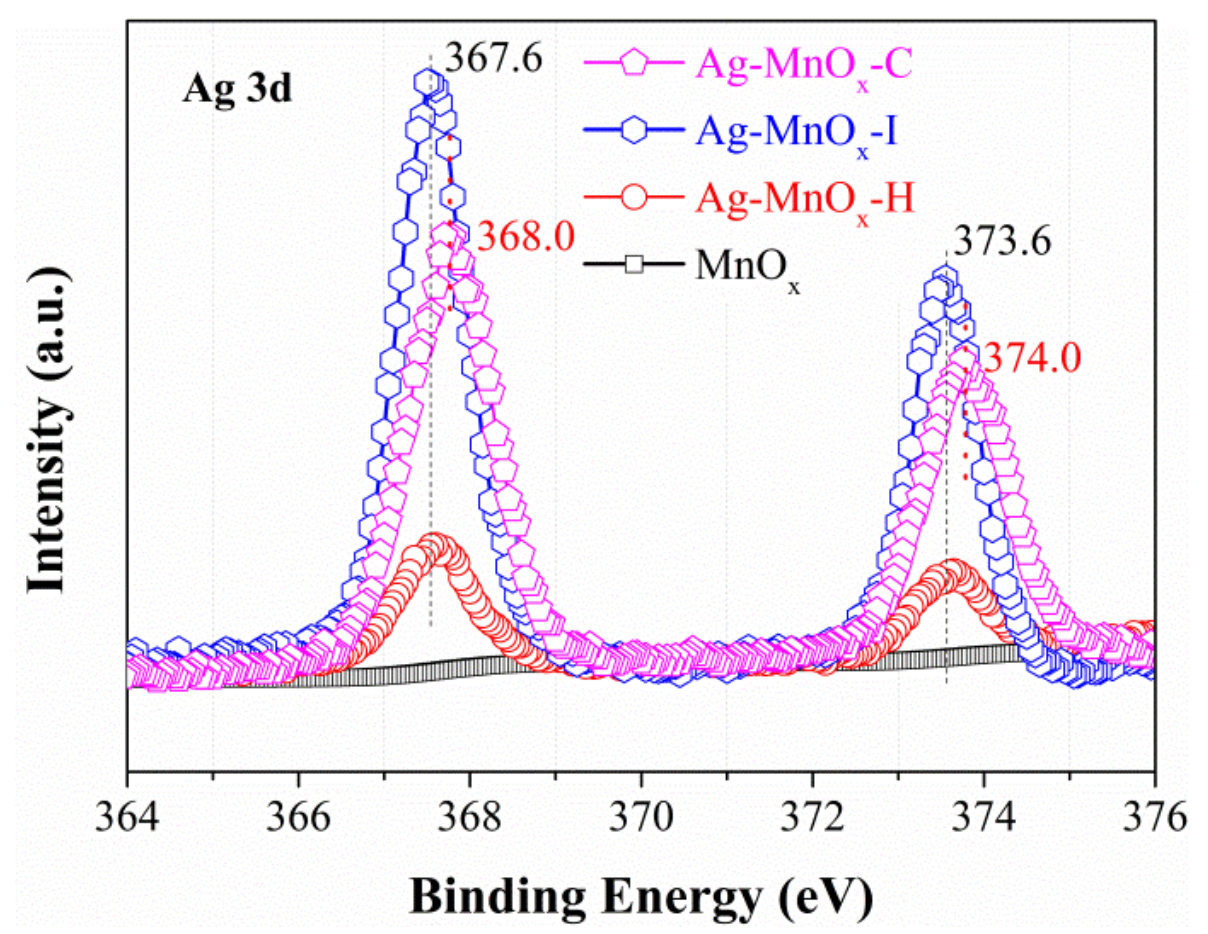

Figure S5. The XPS binding energies of Ag 3d for all Ag-MnOx samples. 
The XPS binding energies of $\mathrm{Ag} 3 \mathrm{~d}$ for all $\mathrm{Ag}-\mathrm{MnO}_{\mathrm{x}}$ samples were determined to investigate the chemical state of silver species, as shown in Figure S5. The Ag $3 d_{5 / 2}$ and $\mathrm{Ag} 3 \mathrm{~d}_{3 / 2}$ BE values of $\mathrm{Ag}-\mathrm{MnO}_{\mathrm{x}}-\mathrm{H}$ and $\mathrm{Ag}-\mathrm{MnO}_{\mathrm{x}}-\mathrm{I}$ were centered at 367.6 and $373.6 \mathrm{eV}$ respectively, which could be attributed to the characteristics of $\mathrm{Ag}^{+}$[13-14]; while the corresponding values of $\mathrm{Ag}-\mathrm{MnO}_{\mathrm{x}}-\mathrm{C}$ shifted slightly to 368.0 and $374.0 \mathrm{eV}$ respectively, which indicated partial formation of $\mathrm{Ag}$ metal species besides the predominant $\mathrm{Ag}^{+}$species [15]. As depicted in Figure $\mathrm{S} 3(\mathrm{C}), \mathrm{Ag}$ species related to Ag-MnOx-C were embedded in the main structure of $\mathrm{Mn}_{2} \mathrm{O}_{3}$ in a very dense state. It is reasonable that the silver species exhibited a partial metallic valence state, as shown in Figure S5.

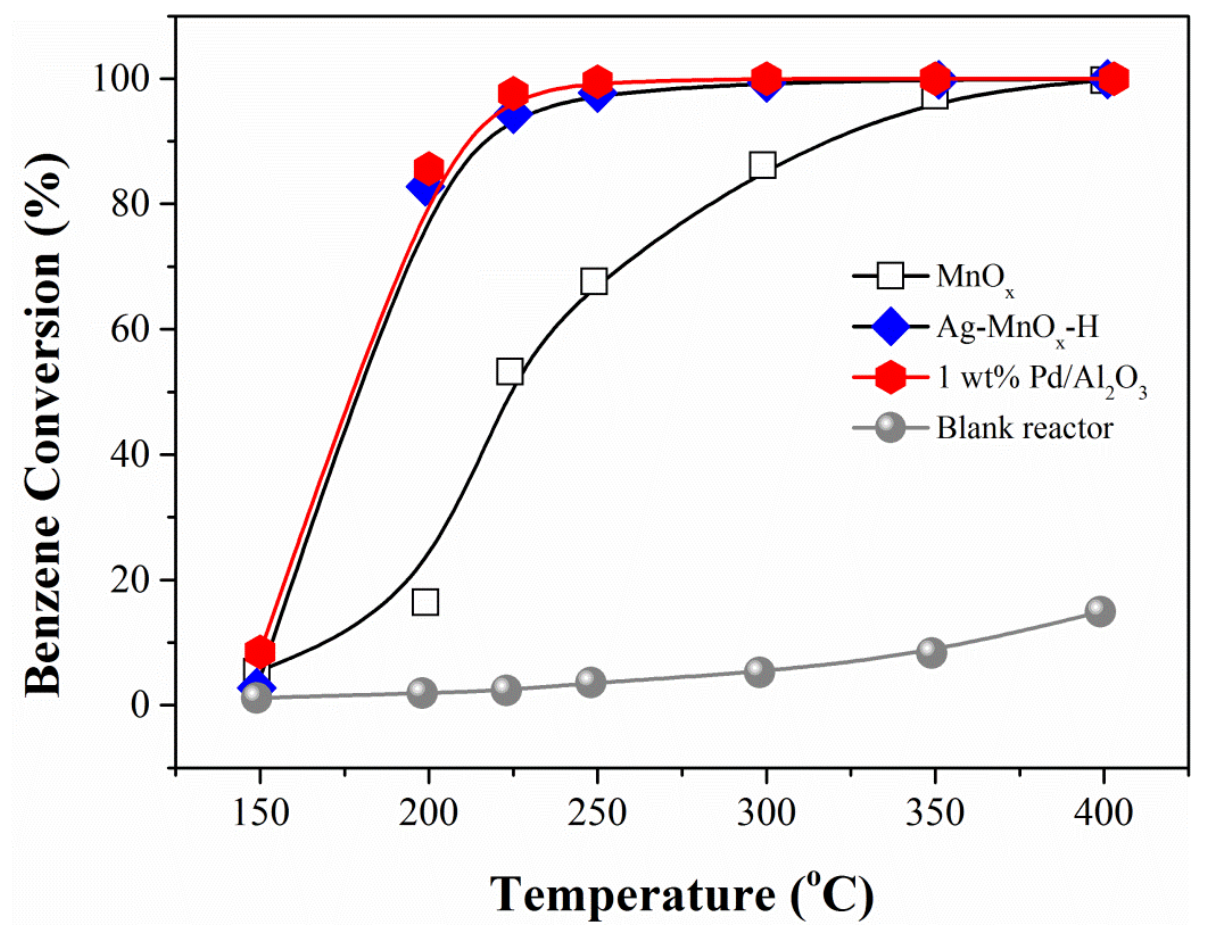

Figure S6. Comparison of $\mathrm{C}_{6} \mathrm{H}_{6}$ conversion (at $\mathrm{SV}=90000 \mathrm{mLh}^{-1} \mathrm{~g}^{-1}$ ) between $\mathrm{Ag}-\mathrm{MnO}_{\mathrm{x}}-\mathrm{H}$ and $1 \mathrm{wt} \% \mathrm{Pd} / \mathrm{Al}_{2} \mathrm{O}_{3}$.

Table S1 Summary of benzene oxidation or ozone decomposition catalysts known to exhibit good performance. 


\begin{tabular}{|c|c|c|c|c|c|c|}
\hline Catalyst & $\begin{array}{l}\text { Weight } \\
(\mathrm{g})\end{array}$ & $\begin{array}{c}\text { benzene } \\
\text { concentration } \\
(\mathrm{ppm})\end{array}$ & $\begin{array}{c}\text { Flow } \\
\left(\mathrm{mL} \cdot \mathrm{min}^{-1}\right)\end{array}$ & $\begin{array}{c}\text { GHSV } \\
\left(\mathrm{mL} \cdot \mathrm{g}^{-1} \cdot \mathrm{h}^{-1}\right)\end{array}$ & $\begin{array}{c}\mathrm{T}_{90} \\
\left({ }^{\circ} \mathrm{C}\right)\end{array}$ & Reference \\
\hline $\begin{array}{c}1 \text { wt. } \% \\
\mathrm{Pd} / \mathrm{Al}_{2} \mathrm{O}_{3}\end{array}$ & 0.2 & 1000 & 100 & 30,000 & 270 & [16] \\
\hline $\begin{array}{c}1 \text { wt. } \% \\
\mathrm{Pd} / \gamma-\mathrm{Al}_{2} \mathrm{O}_{3}\end{array}$ & 0.6 & 1000 & 52.5 & 5250 & 250 & [17] \\
\hline $\begin{array}{l}1.5 \text { wt. } \% \\
\mathrm{Pd} / \mathrm{SiO}_{2}\end{array}$ & 0.1 & 2550 & - & $800 h^{-1}$ & 197 & [18] \\
\hline $\begin{array}{l}0.5 \text { wt. } \% \\
\mathrm{Pt} / \mathrm{Al}_{2} \mathrm{O}_{3}\end{array}$ & 0.05 & 575 & 40 & 48000 & 260 & [19-20] \\
\hline $\begin{array}{l}0.3 \text { wt. } \% \\
\mathrm{Pt} / \mathrm{Al}_{2} \mathrm{O}_{3}\end{array}$ & 0.03 & 250 & 30 & $30000 \mathrm{~h}^{-1}$ & 190 & [21-22] \\
\hline $\begin{array}{l}0.3 \text { wt.\% } \\
\mathrm{Pd} / \mathrm{Al}_{2} \mathrm{O}_{3}\end{array}$ & 0.03 & 250 & 30 & $30000 \mathrm{~h}^{-1}$ & 240 & [21] \\
\hline $\mathrm{Ag}-\mathrm{MnO}_{\mathrm{x}}-\mathrm{H}$ & 0.2 & 1500 & 300 & $\begin{array}{c}90,000 \\
\left(40,000 \mathrm{~h}^{-1}\right)\end{array}$ & 208 & $\begin{array}{l}\text { This } \\
\text { study }\end{array}$ \\
\hline Catalyst & $\begin{array}{l}\text { Weight } \\
(\mathrm{g})\end{array}$ & $\begin{array}{c}\text { Ozone } \\
\text { concentration } \\
(\mathrm{ppm})\end{array}$ & $\begin{array}{c}\text { Flow } \\
\left(\mathrm{mL} \cdot \mathrm{min}^{-1}\right)\end{array}$ & $\begin{array}{c}\text { GHSV } \\
\left(\mathrm{mL} \cdot \mathrm{g}^{-1} \cdot \mathrm{h}^{-1}\right)\end{array}$ & $\begin{array}{l}\mathrm{C}_{6 \mathrm{~h}} \\
(\%) \\
\end{array}$ & Reference \\
\hline $\mathrm{MnFe}_{0.5} \mathrm{O}_{\mathrm{x}}$ & 0.2 & $\begin{array}{c}10000 \mathrm{ppm} \\
25^{\circ} \mathrm{C} \\
\mathrm{RH}=90 \%\end{array}$ & 40 & 12000 & $97 \%$ & [23] \\
\hline $\begin{array}{c}\text { OMS-2 } \\
\left(\alpha-\mathrm{MnO}_{2}\right)\end{array}$ & 0.1 & $\begin{array}{c}40 \\
30^{\circ} \mathrm{C} \\
\mathrm{RH}=90 \%\end{array}$ & 1000 & $\begin{array}{c}600000 \\
\left(560000 \mathrm{~h}^{-1}\right)\end{array}$ & $80 \%$ & [24] \\
\hline Ce-OMS-2 & 0.1 & $\begin{array}{c}40 \\
25^{\circ} \mathrm{C} \\
\mathrm{RH}=90 \%\end{array}$ & 1000 & $\begin{array}{c}600000 \\
\left(600000 \mathrm{~h}^{-1}\right)\end{array}$ & $90 \%$ & [3] \\
\hline $\mathrm{Fe}-\mathrm{MnO}_{\mathrm{x}}$ & 0.1 & $\begin{array}{c}100 \\
25^{\circ} \mathrm{C} \\
\mathrm{RH}=60 \%\end{array}$ & 1100 & 660000 & $73 \%$ & [25] \\
\hline $\begin{array}{c}\alpha-\mathrm{MnO}_{2} \\
\text { vac-200-4h }\end{array}$ & 0.1 & $\begin{array}{c}20 \\
25^{\circ} \mathrm{C} \\
\mathrm{RH}=50 \%\end{array}$ & 900 & $\begin{array}{c}540000 \\
\left(126000 \mathrm{~h}^{-1}\right)\end{array}$ & $50 \%$ & [26] \\
\hline $\mathrm{Ag}-\mathrm{MnO}_{\mathrm{x}}-\mathrm{H}$ & 0.1 & $\begin{array}{c}40 \\
25^{\circ} \mathrm{C} \\
\mathrm{RH}=60 \%\end{array}$ & 1400 & $\begin{array}{c}840000 \\
\left(420000 \mathrm{~h}^{-1}\right)\end{array}$ & $90 \%$ & $\begin{array}{l}\text { This } \\
\text { study }\end{array}$ \\
\hline
\end{tabular}




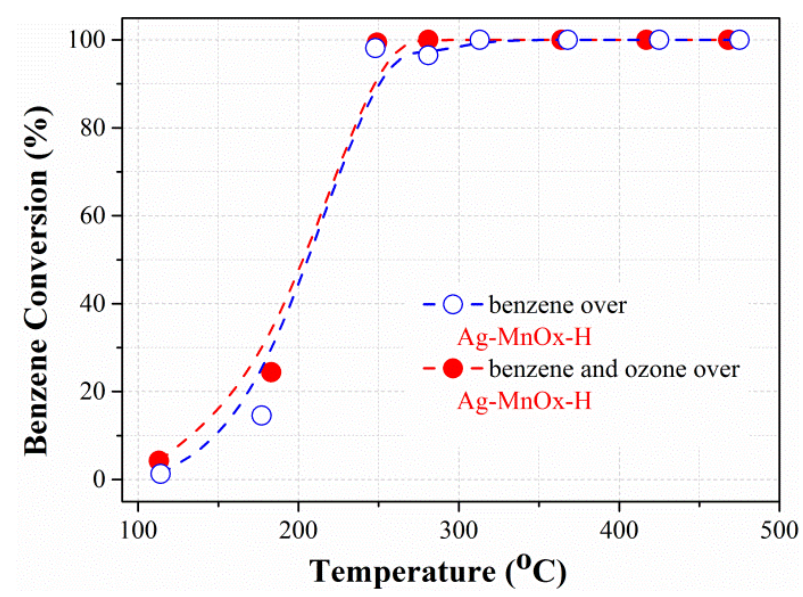

Figure S7. $\mathrm{C}_{6} \mathrm{H}_{6}$ conversion with ozone assistance over $\mathrm{Ag}-\mathrm{MnO}_{\mathrm{x}}-\mathrm{H}$ catalyst as function of temperature (conditions: $\mathrm{C}_{6} \mathrm{H}_{6}(700 \mathrm{ppm}), \mathrm{O}_{3}(125 \mathrm{ppm}$, when used), and

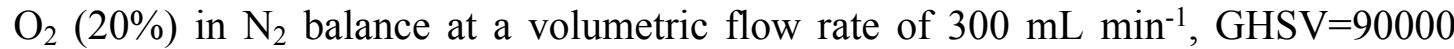
$\left.\mathrm{mLh}^{-1} \mathrm{~g}^{-1}\right)$
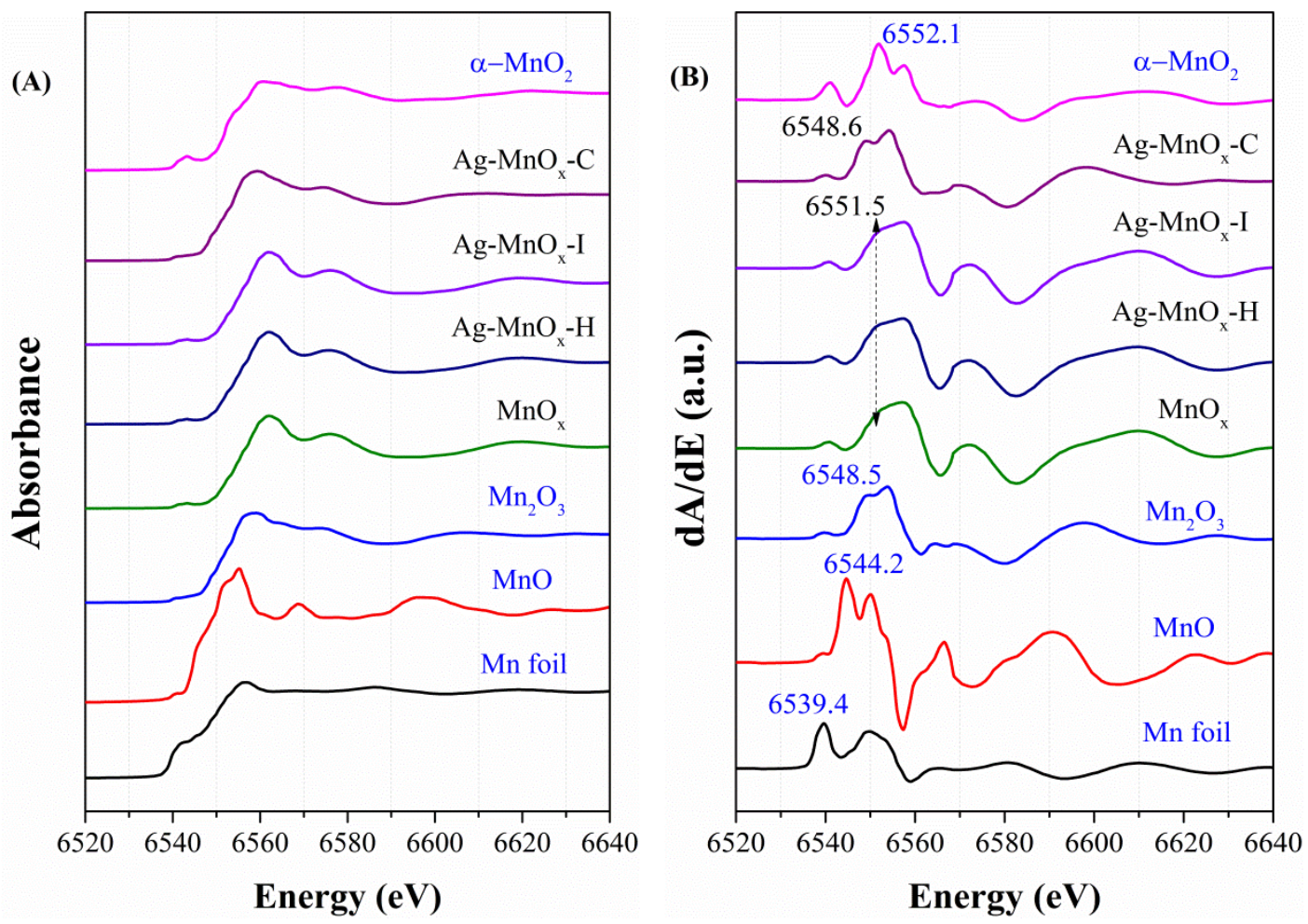

Figure S8. Normalized Mn-K XANES (A), First-order derivatives of Mn-K XANES in in series of Ag-MnOx catalysts (B).

Mn-K XANES of samples derived from different preparation methods were compared to the reference spectra of $\mathrm{MnO}, \mathrm{Mn}_{2} \mathrm{O}_{3}$ and $\alpha-\mathrm{MnO}_{2}$ as shown in Figure S7. The $\mathrm{Ag}-\mathrm{MnO}_{\mathrm{x}}$ catalysts exhibited similar XANES spectra to those of $\alpha-\mathrm{MnO}_{2}$ and $\mathrm{Mn}_{2} \mathrm{O}_{3}$, as shown in Figure $\mathrm{S} 7(\mathrm{~A})$, indicating that $\mathrm{Mn}$ polyhedra in $\mathrm{Ag}-\mathrm{MnO}_{\mathrm{x}}$ appear 
to contain mixed states of $\mathrm{Mn}^{4+}$ and $\mathrm{Mn}^{3+}$. The first-order derivative peak appeared at 6652.1 and $6548.5 \mathrm{eV}$ for $\alpha-\mathrm{MnO}_{2}$ and $\mathrm{Mn}_{2} \mathrm{O}_{3}$ respectively as shown in Figure $\mathrm{S} 7(\mathrm{~B})$. In addition, the first-derivative peaks for $\mathrm{MnO}_{\mathrm{x}}, \mathrm{Ag}-\mathrm{MnO}_{\mathrm{x}}-\mathrm{H}$, and $\mathrm{Ag}-\mathrm{MnO}_{\mathrm{x}}-\mathrm{I}$ catalysts were all observed at $6551.5 \mathrm{eV}$, close to the reference sample of $\alpha-\mathrm{MnO}_{2}$, confirming that $\mathrm{Mn}$ ions in the cryptomelane structure are mainly present as $\mathrm{Mn}^{4+}$. However, the corresponding absorption edge energy for $\mathrm{Ag}-\mathrm{MnO}_{\mathrm{x}}-\mathrm{C}$ appeared at $6548.6 \mathrm{eV}$, close to the reference sample of $\mathrm{Mn}_{2} \mathrm{O}_{3}$, revealing that the $\mathrm{Mn}$ species are still mainly present as $\mathrm{Mn}^{3+}$ even after silver loading.

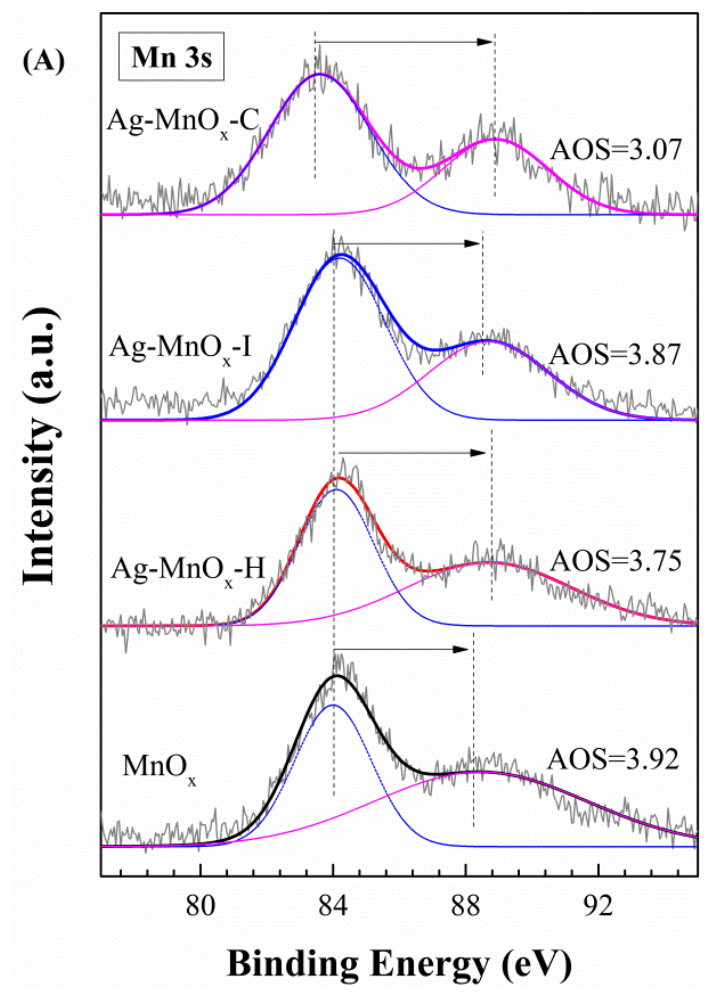

Figure S9. Mn 3s XPS spectra of different Ag-MnOx catalysts

The average oxidation state (AOS) of manganese was also calculated to verify the mixing of valence states. The XPS of Mn 3s were investigated and illustrated in Figure S9. The AOS of all samples were estimated to range from 2.96-3.93 as listed in Table 2. It is clear that $\mathrm{Mn}^{4+}$ is dominant in samples of $\mathrm{MnO}_{\mathrm{x}}, \mathrm{Ag}-\mathrm{MnO}_{\mathrm{x}}-\mathrm{H}$, and $\mathrm{Ag}-\mathrm{MnO}_{\mathrm{x}}-\mathrm{I}$, while $\mathrm{Mn}^{3+}$ is prevalent in samples of $\mathrm{Mn}_{2} \mathrm{O}_{3}$ and $\mathrm{Ag}-\mathrm{MnO}_{\mathrm{x}}-\mathrm{C}$. The AOS value of $\mathrm{Ag}-\mathrm{MnO}_{\mathrm{x}}-\mathrm{H}$ shows an explicit decrease after silver loading, while the corresponding parameter increases for $\mathrm{Ag}-\mathrm{MnO}_{\mathrm{x}}-\mathrm{C}$, indicating that silver introduction could enhance the mixing degree of the Mn valence in cryptomelane and bixbyite. 
This is consistent with the XANES results showing that silver incorporation via hydrothermal and coprecipitation methods could increase the mixing of $\mathrm{Mn}^{3+}$ and $\mathrm{Mn}^{4+}$.

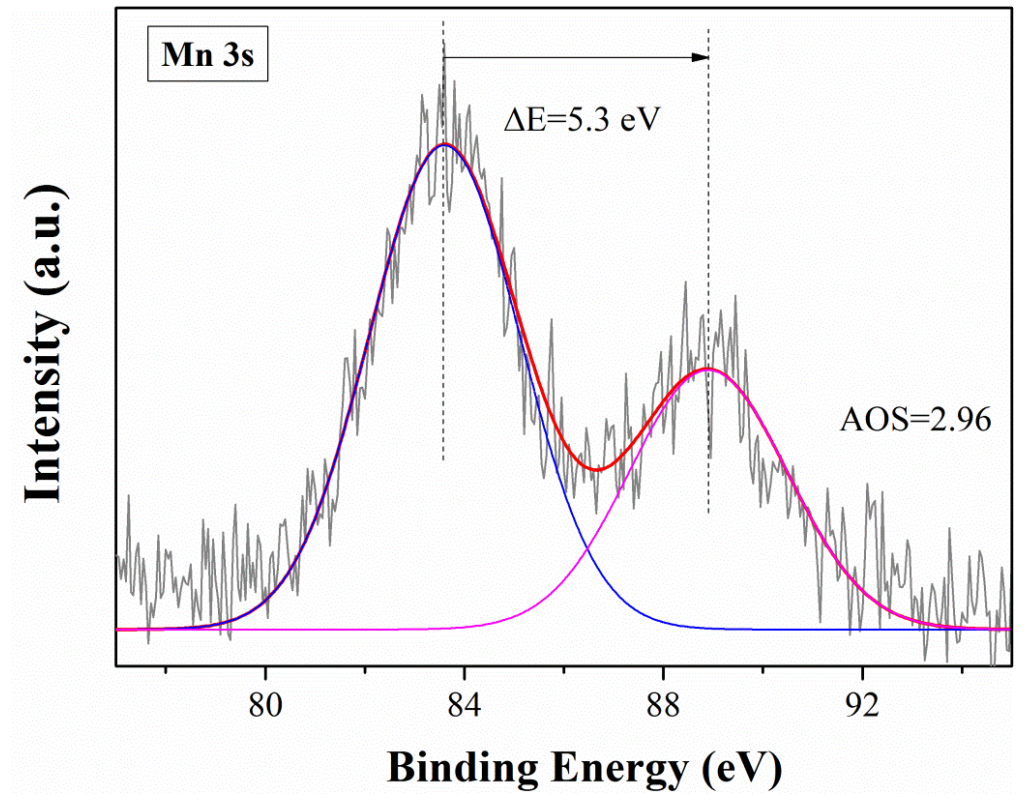

Figure S10. Mn 3s XPS spectra of pristine $\mathrm{Mn}_{2} \mathrm{O}_{3}$ catalyst

Table S2 Peak fitting parameters of O 1s spectra for $\mathrm{Ag}-\mathrm{MnO}_{\mathrm{x}}$ catalysts.

\begin{tabular}{ccccccc}
\hline \multirow{2}{*}{ Sample } & \multicolumn{3}{c}{ Binding Energy (eV) } & \multicolumn{4}{c}{ Relative Contents (\%) } \\
& $\mathrm{O}_{\alpha}$ & $\mathrm{O}_{\beta}$ & $\mathrm{O}_{\gamma}$ & $\mathrm{O}_{\alpha}$ & $\mathrm{O}_{\beta}$ & $\mathrm{O}_{\gamma}$ \\
\hline $\mathrm{MnO}_{\mathrm{x}}$ & 529.6 & 531.4 & 533.0 & 58.2 & 25.2 & 16.6 \\
$\mathrm{Ag}-\mathrm{MnO}_{\mathrm{x}}-\mathrm{H}$ & 529.6 & 531.3 & 533.0 & 73.2 & 21.8 & 5.0 \\
$\mathrm{Ag}^{-\mathrm{MnO}_{\mathrm{x}}-\mathrm{I}}$ & 529.6 & 531.4 & 533.0 & 74.9 & 18.3 & 6.8 \\
$\mathrm{Ag}^{-\mathrm{MnO}_{\mathrm{x}}-\mathrm{C}}$ & 529.8 & 531.3 & 532.7 & 75.2 & 17.1 & 7.7 \\
\hline
\end{tabular}

The asymmetrical O1s spectra could be deconvoluted into three peaks [27-29]. The main peak at a binding energy of 529.6 can be assigned to the lattice oxygen (denoted as $\mathrm{O}_{\alpha}$ ). The peak at a binding energy of 531.4 corresponded to the surface oxygen with low coordination (denoted as $\mathrm{O}_{\beta}$ ), and finally the high binding energy peak at $533.0 \mathrm{eV}$ is likely to be associated with adsorbed molecular water or hydroxyl species (labeled as $\mathrm{O}_{\gamma}$ ). 


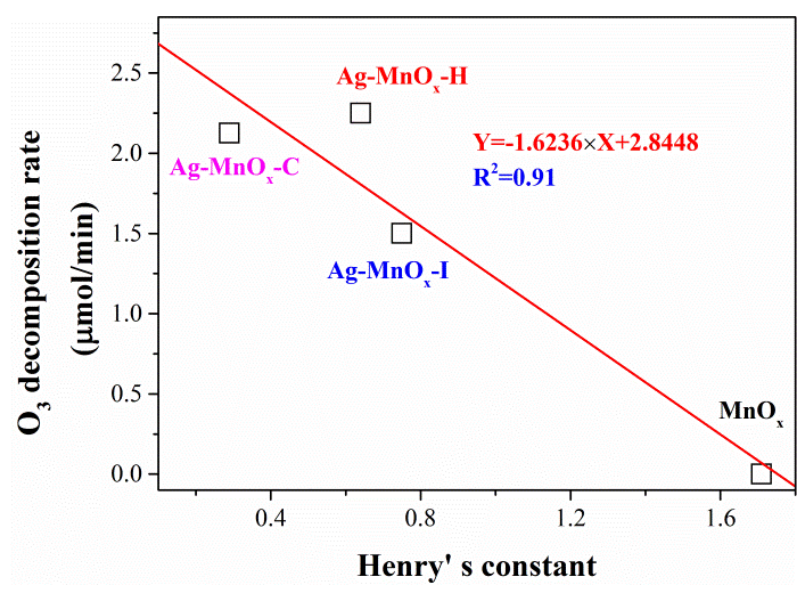

Figure S11. The correlation between $\mathrm{O}_{3}$ decomposition rate and Henry's law constant of water vapor adsorption

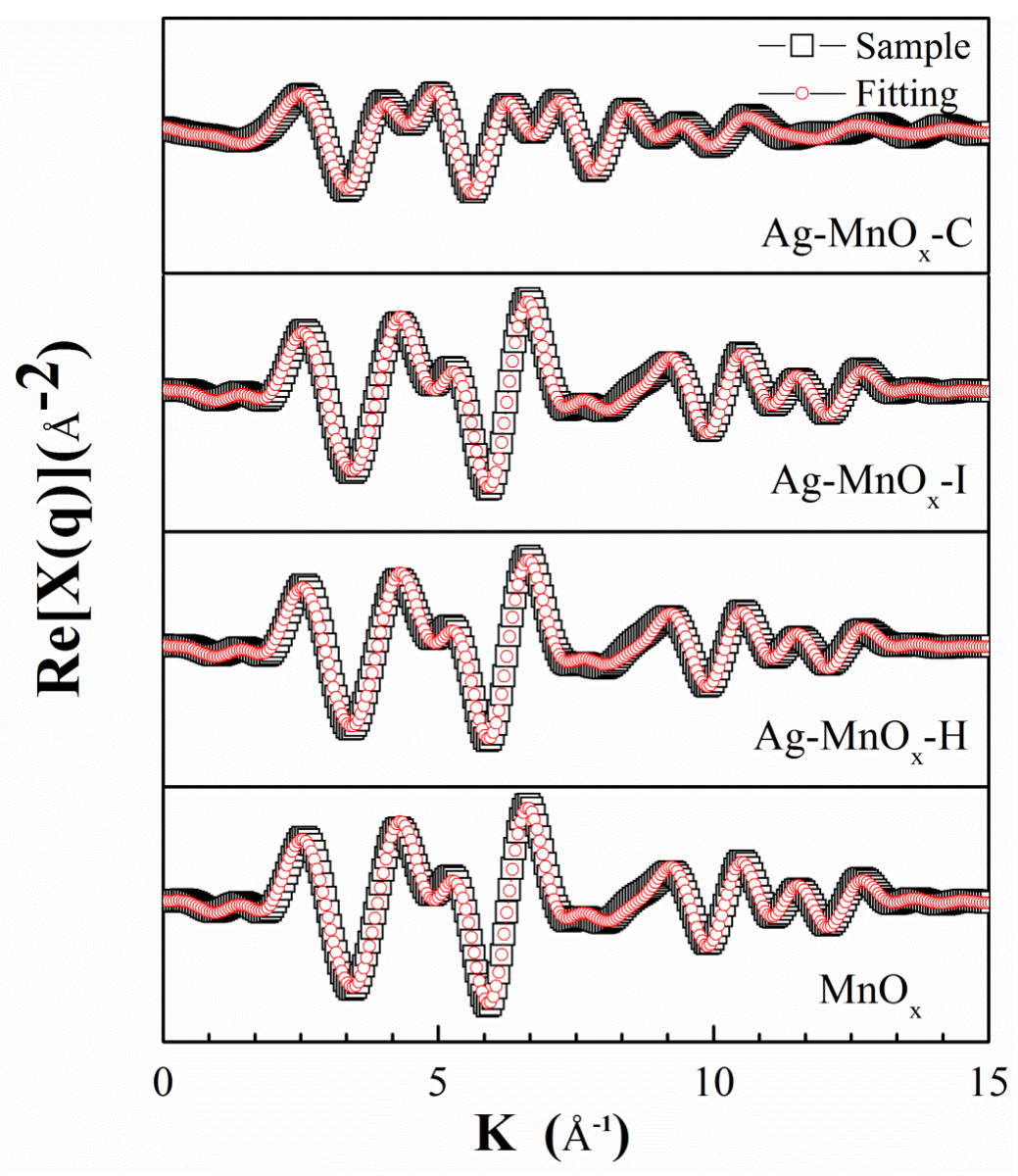

Figure S12. EXAFS spectra of Mn-edge in series of $\mathrm{Ag}-\mathrm{MnO}_{\mathrm{x}}$ catalysts in k space 


\section{References}

[1] S. Dharmarathna, C.K. King'ondu, W. Pedrick, L. Pahalagedara, S.L. Suib, Direct Sonochemical Synthesis of Manganese Octahedral Molecular Sieve (OMS-2) Nanomaterials Using Cosolvent Systems, Their Characterization, and Catalytic Applications, Chem Mater 24 (2012) 705-712.

[2] C.K. King'ondu, N. Opembe, C.H. Chen, K. Ngala, H. Huang, A. Iyer, H.F. Garces, S.L. Suib, Manganese Oxide Octahedral Molecular Sieves (OMS-2) Multiple Framework Substitutions: A New Route to OMS-2 Particle Size and Morphology Control, Adv Funct Mater 21 (2011) 312-323.

[3] J.Z. Ma, C.X. Wang, H. He, Transition metal doped cryptomelane-type manganese oxide catalysts for ozone decomposition, Appl Catal B-Environ 201 (2017) 503-510.

[4] H. Deng, S. Kang, J. Ma, C. Zhang, H. He, Silver incorporated into cryptomelane-type Manganese oxide boosts the catalytic oxidation of benzene, Appl. Catal., B 239 (2018) 214-222.

[5] M. Sun, W.P. Li, B.T. Zhang, G. Cheng, B. Lan, F. Ye, Y.Y. Zheng, X.L. Cheng, $\mathrm{L}$. Yu, Enhanced catalytic performance by oxygen vacancy and active interface originated from facile reduction of OMS-2, Chem Eng J 331 (2018) 626-635.

[6] Z.Y. Li, M.S. Akhtar, P.T.M. Bui, O.B. Yang, Predominance of two dimensional (2D) $\mathrm{Mn}_{2} \mathrm{O}_{3}$ nanowalls thin film for high performance electrochemical supercapacitors, Chem Eng J 330 (2017) 1240-1247.

[7] J. Xu, Y.Q. Deng, Y. Luo, W. Mao, X.J. Yang, Y.F. Han, Operando Raman spectroscopy and kinetic study of low-temperature $\mathrm{CO}$ oxidation on an alpha- $\mathrm{Mn}_{2} \mathrm{O}_{3}$ nanocatalyst, J Catal 300 (2013) 225-234.

[8] R.H. Wang, J.H. Li, Effects of Precursor and Sulfation on OMS-2 Catalyst for Oxidation of Ethanol and Acetaldehyde at Low Temperatures, Environmental Science \& Technology 44 (2010) 4282-4287.

[9] Y. Yang, J. Huang, S.Z. Zhang, S.W. Wang, S.B. Deng, B. Wang, G. Yu, Catalytic removal of gaseous $\mathrm{HCBz}$ on $\mathrm{Cu}$ doped OMS: Effect of $\mathrm{Cu}$ location on 
catalytic performance, Appl Catal B-Environ 150 (2014) 167-178.

[10] J.T. Hou, Y.Z. Li, L.L. Liu, L. Ren, X.J. Zhao, Effect of giant oxygen vacancy defects on the catalytic oxidation of OMS-2 nanorods, J Mater Chem A 1 (2013) 6736-6741.

[11] Y. Luo, Y.Q. Deng, W. Mao, X.J. Yang, K.K. Zhu, J. Xu, Y.F. Han, Probing the Surface Structure of alpha- $\mathrm{Mn}_{2} \mathrm{O}_{3}$ Nanocrystals during $\mathrm{CO}$ Oxidation by Operando Raman Spectroscopy, J Phys Chem C 116 (2012) 20975-20981.

[12] G.I.N. Waterhouse, G.A. Bowmaker, J.B. Metson, The thermal decomposition of silver (I, III) oxide: A combined XRD, FT-IR and Raman spectroscopic study, Phys Chem Chem Phys 3 (2001) 3838-3845.

[13] J.L. Chen, J. Li, H.J. Li, X.M. Huang, W.J. Shen, Facile synthesis of Ag-OMS-2 nanorods and their catalytic applications in CO oxidation, Micropor Mesopor Mat 116 (2008) 586-592.

[14] J.L. Chen, X.F. Tang, J.L. Liu, E.S. Zhan, J. Li, X.M. Huang, W.J. Shen, Synthesis and characterization of Ag-hollandite nanofibers and its catalytic application in ethanol oxidation, Chem Mater 19 (2007) 4292-4299.

[15] M. Ozacar, A.S. Poyraz, H.C. Genuino, C.H. Kuo, Y.T. Meng, S.L. Suib, Influence of silver on the catalytic properties of the cryptomelane and Ag-hollandite types manganese oxides OMS-2 in the low-temperature CO oxidation, Appl Catal a-Gen 462 (2013) 64-74.

[16] S.C. Kim, W.G. Shim, Properties and performance of Pd based catalysts for catalytic oxidation of volatile organic compounds, Appl Catal B-Environ 92 (2009) 429-436.

[17] J. Liu, H.M. Wang, Y. Chen, M.D. Yang, Y.L. Wu, Effects of pretreatment atmospheres on the catalytic performance of $\mathrm{Pd} /$ gamma-A12O3 catalyst in benzene degradation, Catal Commun 46 (2014) 11-16.

[18] S. Lambert, C. Cellier, E.M. Gaigneaux, J.P. Pirard, B. Heinrichs, Ag/SiO2, $\mathrm{Cu} / \mathrm{SiO} 2$ and $\mathrm{Pd} / \mathrm{SiO} 2$ cogelled xerogel catalysts for benzene combustion: Relationships between operating synthesis variables and catalytic activity, Catal Commun 8 (2007) 1244-1248. 
[19] J.T. Hou, L.L. Liu, Y.Z. Li, M.Y. Mao, H.Q. Lv, X.J. Zhao, Tuning the K+ Concentration in the Tunnel of OMS-2 Nanorods Leads to a Significant Enhancement of the Catalytic Activity for Benzene Oxidation, Environ Sci Technol 47 (2013) 13730-13736.

[20] J.T. Hou, Y.Z. Li, M.Y. Mao, X.J. Zhao, Y.Z. Yue, The effect of Ce ion substituted OMS-2 nanostructure in catalytic activity for benzene oxidation, Nanoscale 6 (2014) 15048-15058.

[21] P. Papaefthimiou, T. Ioannides, X.E. Verykios, Combustion of non-halogenated volatile organic compounds over group VIII metal catalysts, Appl Catal B-Environ 13 (1997) 175-184.

[22] Y.X. Chen, Z.W. Huang, M.J. Zhou, Z. Ma, J.M. Chen, X.F. Tang, Single Silver Adatoms on Nanostructured Manganese Oxide Surfaces: Boosting Oxygen Activation for Benzene Abatement, Environ Sci Technol 51 (2017) 2304-2311.

[23] Z.H. Lian, J.Z. Ma, H. He, Decomposition of high-level ozone under high humidity over Mn-Fe catalyst: The influence of iron precursors, Catal Commun 59 (2015) 156-160.

[24] C.X. Wang, J.Z. Ma, F.D. Liu, H. He, R.D. Zhang, The Effects of Mn2+ Precursors on the Structure and Ozone Decomposition Activity of Cryptomelane-Type Manganese Oxide (OMS-2) Catalysts, J Phys Chem C 119 (2015) 23119-23126.

[25] J.B. Jia, W.J. Yang, P.Y. Zhang, J.Y. Zhang, Facile synthesis of Fe-modified manganese oxide with high content of oxygen vacancies for efficient airborne ozone destruction, Appl Catal a-Gen 546 (2017) 79-86.

[26] G.X. Zhu, J.G. Zhu, W.J. Jiang, Z.J. Zhang, J. Wang, Y.F. Zhu, Q.F. Zhang, Surface oxygen vacancy induced alpha-MnO2 nanofiber for highly efficient ozone elimination, Appl Catal B-Environ 209 (2017) 729-737.

[27] W.X. Tang, X.F. Wu, D.Y. Li, Z. Wang, G. Liu, H.D. Liu, Y.F. Chen, Oxalate route for promoting activity of manganese oxide catalysts in total VOCs' oxidation: effect of calcination temperature and preparation method, J Mater Chem A 2 (2014) 2544-2554. 
[28] V.P. Santos, M.F.R. Pereira, J.J.M. Orfao, J.L. Figueiredo, The role of lattice oxygen on the activity of manganese oxides towards the oxidation of volatile organic compounds, Appl Catal B-Environ 99 (2010) 353-363.

[29] Y.X. Chen, Z.W. Huang, M.J. Zhou, Z. Ma, J.M. Chen, X.F. Tang, Single Silver Adatoms on Nanostructured Manganese Oxide Surfaces: Boosting Oxygen Activation for Benzene Abatement, Environ Sci Technol 51 (2017) 2304-2311. 